JIŘí ŠUBRT

\title{
PAMĚŤ JAKO SOCIOLOGICKÝ PROBLÉM
}

Problém paměti nepatří v sociologii $\mathrm{k}$ běžným nebo častým námětům teoretických úvah či empirického zkoumání, přesto mu významné místo v rámci této vědní disciplíny nepochybně náleží. Ze společenských věd to byla doposud spĩse psychologie na jednom a historické vědy na druhém pólu, které vưči tomuto fenoménu projevovaly větší pozornost a vnímavost. Inspirativní v tomto směru jsou pro sociologii zejména některé výzkumné projekty, realizované v poslední době z iniciativy historiků. Zdá se, že interdisciplinární spolupráce mezi historiky a sociology může na tomto poli přinášet zajímavé plody.

Zájem o dané téma prožívá v posledních letech určitou konjunkturu; někdy se dokonce hovoří o jeho „virulenci“. Tento interes se dává do souvislosti s celou řadou faktorů, $\mathrm{k}$ nimž patří jak nová elektronická média s umělými pamětmi a problematika umělého intelektu, tak rozsáhlé diskuse o moderně a postmoderně, reflexe soudobého stavu evropské kultury, hledání identity, transformační procesy probíhající ve střední a východní Evropě. Jedním z významných motivů je i to, že proživáme dobu zániku živých vzpomínek na nejtěžší zločiny a katastrofy v análech lidských dějin, nebot postupně odchází generace jejich svědků. Čtyřicet let znamená z hlediska kolektivních vzpomínek jednu epochální vlnu.

Všechny tyto skutečnosti vedou některé badatele k závěru, že otázka paměti a koncepty s ní spojené vytvářejí nové paradigma kulturních věd /Assmann 1992: 11/, které nahlíží oblast společnosti, politiky, práva, náboženství, umění a literatury v nových souvislostech. I sociologie, jak se zdá, by měla výrazněji reflektovat skutečnost, že at už se v jejím rámci zabýváme jakoukoliv otázkou, pamět vždy vystupuje jako určitý (často zamlčený) předpoklad. 


\section{KOLEKTIVNÍ PAMĚŤ}

První, kdo obrátil významějším zpúsobem pozornost sociologie směrem k paměti, je francouzský sociolog Maurice Halbwachs (1877-1945). $\left.{ }^{1}\right)$ Halbwachs věnoval této problematice několik prací.

Patří k nim Les Cadres sociaux de la Mémoire (1925), La Topographie légendaire des Evangelies en Terre sainte, étude de mémoire collective (1942). Z jeho posledního díla, kterým chtěl zkoumání na tomto poli uzavř́it, byly nalezeny pouze fragmenty, jež byly editorsky zpracovány jeho dcerou Jeanne Alexandre a pod titulem La Mémoire collective zveřejněny v r. 1950.

Koncept kolektivní paměti, který představuje jádro uvedených spisů, nese evidentně stopy vlivu dvou významných Halbwachsových učitelů, $\mathrm{H}$. Bergsona a E. Durkheima. V Bergsonově filozofickém systému hraje pamět jednu z klíčových rolí. Pokud jde o Durkheima, inspirativní úlohu zde sehrála bezpochyby jeho teorie kolektivního vědomí. Durkheim a jeho žáci navíc byli první, kteří v rámci sociologie (ovlivněni do určité míry právě Bergsonem) výrazněji upozornili na problém času. Proto nyní učiníme menší odbočku a stručně se zmíníme i o těchto otázkách, i když se našeho problému dotýkají spî̃e nepřímo.

\section{Čas a pamět ve filozofii Henriho Bergsona}

Bergson spatřoval překážku adekvátního pochopení času v tendenci aplikovat na něj prostorové představy. Tato tendence způsobuje, že čas chápeme jako přímku, na níž leží minulost i budoucnost, vzájemně odděleny momentem přítomností: podobně jako se zaznamenává melodie v podobě určitého pořadí not (odpovídajících jednotlivým tónům) do notových linek. Jedním z důsledků této analogie je, že časový okamžik chápeme jako bod na př́mce, jednotlivé časové momenty považujeme za stejnorodé a čas podobně jako přímku za nekonečně dělitelný. Jinak řečeno: vytváŕíme $\mathrm{z}$ času stejnorodé prostř̌edí, $\mathrm{v}$ němž se pak odvíjejí jednotlivé procesy a pochody. Je to představa prázdného, homogenního času (vlastní např. newtonovské mechanice), v němž se př́tomnost posouvá jako bod po přímce. Podle Bergsona je toto pojetí problematické tím, že zabraňuje pochopit čas v jeho souvislém postupném

1) Halbwachs byl zpočátku ovlivněn Henri Bergsonem; již na lyceu patřil k jeho studentům. Poté, co ukončil univerzitní studia, se však orientoval na sociologii. Byl předním žákem a spolupracovníkem Emila Durkheima. V jeho časopise L'Année sociologique publikoval od r. 1904. Spektrum Halbwachsových odborných zájmů bylo poměrně široké. Inspirován $\mathrm{A}$. Quételetem, zabýval se statistikou, dále ekonomikou, demografií, psychologií a sociální psychologií. Věnoval pozornost zejména postavení dělnické tř́ídy (La classe ouvrière at les niveaux de vie (1913), L'Evolution des besoins dans les classes ouvrières (1933)). Ve své badatelské práci používal i kvantitativní výzkumné metody. Byl profesorem na štrasburkské univerzitě a na pařížské Sorboně. Za druhé světové války byl Halbwachs jako príslušník Hnutí odporu zatčen fašisty. V r. 1945 zemřel v Buchenwaldu. 
rozvíjení, tzn. jako čas-trvání (temps-durée), a vede do absurdností, na které poukázaly už Zenónovy aporie.

Rozhodující se při řešení otázky času pro Bergsona stala analýza vnitřních, duševních dějů. Za klíčové považuje jejich trvání (durée). Trvání lze demonstrovat na známém příkladu vnímání melodie, které dokládá, že duševní dění není sledem ohraničených stavů, nýbrž vzájemně se prostupujících kvalit. Určitý duševní stav se podle Bergsona mění už jenom tím, že trvá, i když třeba jen velice krátkou dobu: jde-li např. o zrakový vjem nehybného, neměnného předmětu, pozorovaného ze stejného místa, pod stálým úhlem a za stejného osvětlení, liší se názor, který mám na tento předmět, od názoru, který jsem o něm měl před malým okamžikem, už jenom tím, že př́tomný okamžik je bohatší o vzpomínku na okamžik předchozí /Bergson 1919: 12/.

Tato vzpomínka je tedy oním prvkem (analogickým novému tónu v melodii), jímž trvání získává nový kvalitativní odstín, který tu v minulosti nebyl. Plynutí času pak spočívá právě v tomto plynulém přistupování stále nových, vzájemně se prolínajících prvků paměti, které umožňují přirovnat vědomí $\mathrm{k}$ neustále pokračující melodii. Ovšem nejen vědomé bytosti, ale i živé organismy a nakonec i vesmír jako celek jsou podle Bergsona něčím, co trvá. Trvání znamená neustálé vytváření čehosi nového (Bergson v této souvislosti hovoř́ o času-invenci), což způsobuje ireverzibilitu času. Předvídání budoucích momentů našich vniť̌ních dějů není možné, protože představit si nějaké nové stavy v jejich plnosti znamená prožít ve stejném rytmu rozvoje to, co jim předcházelo.

Uvedená teorie se pro Bergsona stala novým metafyzickým východiskem, představujícím jádro jeho filozofie života. „Všude, kde něco žije “ “řká Bergson, „leží otevřená protokolní kniha, do níž se zapisuje čas" /op. cit.: 31/. Pamět je předpokladem vědomí, trvání a času. Díky ní jsme sami sebou a rozumíme věcem kolem sebe.

Pro Halbwachse byly tyto myšlenky inspirativní, ovšem pod Durkheimovým vlivem zaměřil svůj výzkumný zájem poněkud jiným směrem, na sociální realitu.

\section{Durkheimův koncept kolektivního vědomí}

Halbwachs byl výrazně ovlivněn „sociologismem“ Durkheimovy školy, který chápal sociální skutečnost jako zvláštní, na jednotlivce nepřevoditelnou kvalitu. Sociální celek není podle tohoto názoru totožný s částmi, které jsou v něm obsaženy. Durkheim ostře kritizoval př́stup svého současníka Gabriela Tarda, který založil výklad společnosti na studiu individuální psychiky. Durkheim zřetelně rozlišoval individuální a kolektivní úroveň vědomí. Seskupováním a kombinováním individuálních vědomí vzniká něco nového: „Skupina myslí, cítí, jedná zcela jinak, než by jednali její členové, kdyby byli osamoceni““/Durkheim 1926: 136/. Fakt společného vědomí nelze vyložit na základě poznatků o individuální psychice.

Kolektivní vědomí je pro Durkheima odpovědí na otázku, co je předmětem sociologie. Pokud by reálně neexistovalo nic kromě individuálního vědomí, neměla by 
sociologie nárok být samostatnou vědou (byla by pouze nadstavbou psychologie). Kolektivní vědomí umožňuje existenci sociologie samé, nebơ jí dává vlastní předmět. Má to ovšem i své metodologické konsekvence: V sociologickém bádání je třeba vyloučit dokumenty osobní povahy a čerpat $\mathrm{z}$ takových materiálů, ve kterých se projevuje vědomí kolektivní, tj. z právních kodexů, náboženských dogmat, etických norem atd.

Vedle pojmu kolektivní vědomí používal Durkheim také výraz kolektivní představy, sloužící $\mathrm{k}$ vyjádření spontánních, neregulovaných a emocionálně zabarvených obecných věr a idejí. Příčiny vzniku kolektivního vědomí a kolektivních predstav spatřuje Durkheim nikoliv ve stavech individuálních vědomí, nýbrž v podmínkách, v nichž se nalézá společnost jako celek.

S konceptem kolektivního vědomí se setkáváme ve všech významných Durkheimových pracích: De la division du travail social (1893), Les règles de la méthode sociologique (1895), Le suicide (1897), Représentations individuelles et représentations collectives (Revue de métaphysique et de morale 1898), Les formes élémentaires de la vie religieuse (1912).

Durkheimovy názory na kolektivní vědomí se vyvíjely. Zejména ve svých pozdějších pracích spatřoval Durkheim v kolektivním vědomí nejdůležitější složku života společnosti, ba př́mo její podstatu. Současně ovšem polemizoval s názory, které jeho koncepci vytýkaly, že chápe a vykládá společnost jako transcendentní, hypostázovaný a substancionální celek. To, že kolektivní vědomí může existovat nezávisle na projevech individuálního vědomí, ještě podle Durkheima neznamená, že může existovat společnost bez individuí. Aby bylo možné rozlišení mezi individuálním a kolektivním vědomím, říká Durkheim, ,není nutno hypostázovat kolektivní vědomí; ono je něčím zvláštním a musí být označováno zvláštním výrazem prostě proto, že stavy, z nichž sestává, se specificky liší od stavů, z nichž sestávají jednotlivá vědomí. Ten specifický ráz pochází odtud, že nejsou vytvořeny z týchž prvkủ. Jedny vyplývají z přirozenosti organicko-psychické bytosti, vzaté ojediněle, druhé ze sestavy mnoha bytostí toho druhu. Výslednice se tedy musejí nutně lišit, když se složky liší v té mîre" /op. cit.: $136 /$.

\section{Problém času v pojetí Durkheimovy sociologické školy ${ }^{2}$ )}

Fenomény, se kterými se ve společnosti setkáváme, nejsou podle Durkheima redukovatelné na individuální vědomí. Zkoumáme-li konstituci času, musíme se zabývat nikoliv prírodou nebo vědomím jednotlivců, nýbrž povahou společnosti, kolektivními představami a kolektivním vědomím.

Prvním významnějším zpracováním problematiky času ze sociologického a etno-

$\left.{ }^{2}\right)$ Podrobnějǔś informaci najde čtenář v článku $\mathrm{K}$ vývoji názorů na problém času v sociologii /Šubrt 1993/. 
logického pohledu byla studie Durkheimových žáků H. Huberta a M. Mausse Étude sommaire de la representation du temps dans la religion et la magie (1909). Jí ovšem předcházela Durkheimova a Maussova společná stą De quelques formes primitives de classification (1901/1902), v níž se mj. pojednává o problematice dělení času, a v níž autoři konstatují, že primitivní formy klasifikace včetně abstraktních úvah o čase a prostoru mají sociální původ a jsou závislé na příslušné formě společnosti.

Hubertova a Maussova studie z r. 1909 prozrazuje kromě Durkheimova vlivu (postulát vysvětlovat sociální pouze prostřednictvím sociálního) rovněž určitou dávku bergsonovské inspirace. Oba autoři se zde zabývají původními představami o čase v náboženství a magii, které měly (na rozdíl od kvantitativních prèdstav dominujících v moderní společnosti) výrazně kvalitativní povahu. Čas v těchto představách není libovolně dělitelný, obsahuje kritická data (jejich význam bývá zdůrazněn rituály), která přerušují jeho kontinuitu, a určité homogenní, vnitřně nedělitelné periody. Úkolem kalendáře není měřit čas, nýbrž zajištovat rytmus kolektivního života a jeho pravidelnost. Bergsonova terminologie je $\mathrm{v}$ této stati použita v poněkud posunutém významu, pokud jde o pojem durée, rozdíl je podstatný: neoznačuje se jím vnitřní časový prožitek nýbrž kvalitativní aspekty sociálně náboženského času.

$\mathrm{V}$ knize Les formes élémentaires de la vie religieuse (1912) označuje Durkheim čas za jednu ze základních kategorií našeho uvažování, které mají počátek v náboženství a jsou produkty religiózního myšlení. Náboženství má podle Durkheima sociální původ. Náboženské představy jsou představy kolektivní, vyjadřující kolektivní skutečnosti. Kategorie, o kterých Durkheim hovoří, jsou vyvozeny nebo vyabstrahovány $\mathrm{z}$ kolektivního života lidí a jejich obsah vyjadřuje různé společenské formy nebo aspekty sociálna. Dělení času na dny, týdny, měsíce atd. odpovídá rytmům kolektivního života a periodicitě rituálů, slavností a veřejných ceremonií. Sociální povahu času nemůže zpochybnit ani to, že kritická data jsou obvykle totožná s nějakým př́rodním jevem (nap̌r. s pohybem hvězd), protože tato skutečnost slouží pouze $\mathrm{k}$ jeho objektivnímu značení v rámci sociální organizace /Durkheim 1981: 591/.

\section{Halbwachsova teorie sociálních rámců kolektivní pamèti}

V Halbwachsově teoretickém díle hraje významnou roli teze o sociální podmíněnosti paměti. Lidská pamět může podle něj existovat pouze proto, že existuje kolektivní pamět. Od biologické báze této paměti, dané činností mozku, Halbwachs odhliží. Soustředuje svoji pozornost na vzájemné sociální působení, které je pro něj rozhodujícím faktorem zapamatování. Tvrdí, že individuum vyrostlé v naprosté izolovanosti žádnou pamět nemá. Tu získává až v procesu socializace.

Kolektivní život je zdrojem jak vzpomínek samých, tak i pojmů, v nichž se tyto vzpomínky ztělesňují. Vzpomínáme na to, co je komunikováno, a co je jako takové lokalizováno v kolektivní paměti. Pamět se konstituuje, funguje a reprodukuje v určitých sociálních rámcích. Tyto rámce vytvářejí lidé žijící ve společnosti. V nich jsou 
naše vzpomínky fixovány a vyvolávány. Jimi je určena významnost toho, nač vzpomínáme. ${ }^{3}$ )

Halbwachsova koncepce vysvětluje i proces zapomínání. Jestliže subjekt paměti vzpomíná na to, co bylo $\mathrm{v}$ určitém rámci, $\mathrm{v}$ určité přítomnosti rekonstruováno jako minulost, pak zapomíná na to, co v této prítomnosti takový rámec nemá. Zapomínání souvisí tedy se změnou nebo se zmizením př́slušného rámce /Halbwachs 69: 406/.

Halbwachs odlišuje individuální a kolektivní pamět. Ovšem i individuální pamět je pro něj sociálním fenoménem. Individuální, př́íně vzato, jsou pouze vjemy. Vzpomínky (i osobní povahy) mají svůj původ v myšlení skupiny, v komunikaci a interakci, které v jejím rámci probíhají. Jednotlivci umožňuje jeho pamět podílet se na obsahovém bohatství kolektivní paměti. Individuální pamět je místem specifického propojení kolektivních pamětí různých sociálních skupin. Z hlediska skupiny se naproti tomu celá věc jeví jako otázka distribuce vědění mezi její jednotlivé členy. Ten, kdo má účast na kolektivní paměti, tím osvědčuje svoji skupinovou př́slušnost.

V Halbwachsově koncepci se odráží jeho sociálně psychologická orientace. Zabývá se kolektivní pamětí rodiny, náboženských společenství, sociálních tříd a národů. Používá mj. i výrazy skupinová pamět a pamět národa. ${ }^{4}$ ) Kolektivní pamět není pro Halbwachse pouze nějakým metaforickým označením, nýbrž živou realitou ( $v$ tomto smyslu je tedy sociologickým realistou, nikoliv nominalistou). Kolektiv pro něj představuje subjekt paměti. ${ }^{5}$ )

Vše, co vstupuje do paměti, každá osobnost, historický fakt atd. získává při tomto vstupu formu elementu (pojmu, symbolu, učení) systému idejí př́slušné společnosti. Halbwachs $v$ této souvislosti hovoří o obrazech vzpomínek. ${ }^{6}$ ) Obrazy vzpomínek souvisejí s určitým konkrétním časem a prostorem. Jsou tedy časově a prostorově konkrétní, i když mnohdy ne $\mathrm{v}$ přísně historickém a geografickém smyslu. $\mathrm{V}$ tomto smyslu odráží časovou dimenzi paměti kalendář a v něm uspořádaný systém svátků. Prostorově bývají vzpomínky zakotveny napr. k tomu, co reprezentuje domov: dům, vesnice, město, země.

$\mathrm{K}$ prostoru náleží také určitý systém věcí a objektů. Skupina, která je nositelem kolektivní paměti, směřuje k tomu vytvořit a zajistit si místa, která slouží k udržení vzpomínek. Tato místa jsou symbolem její identity. Pamět potřebuje prostor, tenduje k zprostorovění. Halbwachs tuto tendenci dokládá studií o evangelické legendární

${ }^{3}$ ) J. Assmann poukazuje na afinitu mezi Halbwachsovým konceptem sociálních rámců a teorií analýzy rámců vyvinutou $\mathrm{E}$. Goffmanem, za účelem zkoumání organizace každodenních zkušeností. Halbwachsova analýza rámce vzpomínek je analogická k Goffmanově analýze rámce zkušeností a používá obdobnou terminologii.

$\left.{ }^{4}\right)$ G. Namer v odkazu na tyto Halbwachsovy analýzy hovoří o pluralitě kolektivních pamětí /Namer 1987: $85 \%$.

$\left.{ }^{5}\right)$ Je to poněkud jiné chápání kolektivnîho než třeba u C. G. Junga, v jeho teorii kolektivního nevědomí a archetypů. Pro Junga je oblast nevědomí, kterou se zabývá, biologicky dědičná a projevuje se spontánně (např. prostřednictvím snů). Halbwachs naproti tomu zůstává v oblasti, v níž dochází k přenosu díky sociální komunikaci a v níž je pamět aktivována volními akty.

6) J. Assmann naproti tomu razí pojem ,figury vzpomínek“, který je podle jeho názoru vhodnější, nebot' ho lze vztáhnout jak na ikonické, tak i na narativní útvary /Assmann 1992: 38/. 
topografii svatých zemí, v níž mj. ukazuje, že skupiny mohou vstupovat do určitého symbolického společenství s prostorem, i když jsou od něho fakticky odděleny. Tento prostor je pak symbolicky reprodukován jako svatá země apod.

Čas a prostor mají význam pro sebereflexi skupiny a pro formulaci jejích cílů. Sociální skupiny, které se konstituují na bázi určitého pospolitého vzpomínání, svoji minulost ochraňují a střeží. Důležité je v tomto směru jednak vědomí jedinečnosti, pramenící z diferenciace vzhledem k okolnímu světu, jednak vědomí identity, trvání $\mathrm{v}$ čase, které je pěstováno s péčí o zapamatované fakty a o jejich výběr. Souvislost mezi pamětí a strukturou společnosti ilustruje Halbwachs na př́kladu středověkého feudálního systému, v němž postavení rodiny ve velké mî̃e záviselo na tom, co ví o minulosti své i ostatních rodin. Pamět, můžeme říci, legitimizovala nárok na určitá privilegia, kompetence či funkce.

Jiným významným rysem kolektivní paměti je rekonstruktivita /op. cit.: 137/. $\mathrm{V}$ žádné paměti není totiž minulost udržována jako taková, nýbrž v té podobě, kterou daná společnost, $v$ nějaké konkrétní době a v konkrétním sociálním rámci, zachytila. To, že pamět postupuje rekonstruktivně, znamená, že obraz minulosti v ní není stálý. Minulost je v průběhu času reorganizována. Nové události či změny přnnášejí nový pohled na minulost, a tedy i její restrukturalizaci.

Halbwachs proti sobě klade kolektivní pamět a historii. Skupina podle Halbwachse tenduje $\mathrm{k}$ tomu vytěsnit $\mathrm{z}$ obrazu své minulosti změnu (vnímat své trvání jako neměnné). V sebereflexivním pohledu zdůrazňuje pamět podobnost a kontinuitu. Dějiny naproti tomu postupují obráceně, vnímají především diskontinuitu a diference. Čas beze změny historie vymazává jako prázdný interval.

Další rozdíl spočívá v tom, že skupinová pamět zdůrazňuje vlastní odlišnost vưči okolí, tzn. čím se skupina odlišuje ve svých vlastních dějinách od jiných skupin. Historie naopak všechny takové diference nivelizuje a reorganizuje svá fakta ve zcela homogenním historickém prostoru. V něm není nic jedinečného, ale vše je naopak srovnatelné se vším. Každý jedinečný děj je připojitelný $\mathrm{k}$ jinému a všechny jsou stejně důležité a významné.

V Halbwachsově pojetí existuje mnoho kolektivních pamětí, ale jen jedna historie, která je zbavena každého specifického zřetele. ${ }^{7}$ ) Odhlédneme-li od toho, že doména historiků je spĩse v oblastech, které jsou mimo rámec kolektivních pamětí, můžeme konstatovat zhruba toto: na jedné straně existuje mnoho dějin uchovávaných v mnoha skupinových pamětech, na druhé straně jsou jedny univerzální dějiny, do nichž historikové umistují data $\mathrm{z}$ mnoha skupinových dějin. $\mathrm{Z}$ tohoto hlediska je pro Halbwachse historický čas „umělé trvání", které není žádnou skupinou jako „durée" prožíváno /Halbwachs 1967: 100/.

$\left.{ }^{7}\right)$ Tento závěr je předmětem kritiky, která Halbwachsovi vytýká pozitivistický př́stup k historii, který přehliž́í, že každé psaní dějin, podobně jako kolektivní pamět', je ovlivněno dobou a zájmy svého pisatele. 


\section{KOMUNIKATIVNÍ A KULTURNÍ PAMĚŤ}

Je určitou ironií osudu, poznamenává Jan Assmann, že M. Halbwachs, teoretik sociální paměti, byl na dlouhá léta zapomenut. Zájem o jeho dílo vzrostl v 80 . letech. Mezi ty, které Halbwachs inspiroval, patří právě Assmann, z jehož studií, věnovaných otázce paměti, je třeba upozornit zejména na knihu Das kulturelle Gedächtnis z r. 1992. Assmann je profesí egyptolog, který se mj. zabývá otázkou písemné kultury, formami historického vědomí, kulturní a politickou identitou raných kultur. Jeho práce ovšem současně prozrazují i výraznou sociologickou erudici a jsou bezpochyby v tomto směru př́nosné. Sám Assmann zařazuje své úvahy o sociální paměti do oblasti všeobecné kulturní teorie.

V návaznosti na Halbwachse Assmann konstatuje, že předmětem kulturních věd není individuální pamět, jako vnitřní fenomén lokalizovaný v mozku, nýbrž vnější dimenze lidské paměti, kterou lze označit výrazem kolektivní pamět. Co tato pamět obsahově přijímá, jak je organizována a jak dlouho uchovává jednotlivé obsahy, to všechno jsou otázky nikoliv vnitřní kapacity a vnitřního řízení, nýbrž otázka vnějších, tzn. společenských a kulturních rámců. Tematicky rozlišuje Assmann čtyři oblasti paměti:

a) Mimetická pamět. Vztahuje se na oblast sociálnîho jednání a souvisí s tím, že jednání se učíme pomocí napodobování. Assmann má na mysli skutečné napodobování; řîká, že i přes existenci písemných návodů a receptů je jednání něčím, co nelze takto plně kodifikovat, a proto stále zůstávají velké oblasti jednání, které se zakládají na zvycích, obyčejích a mimetické tradici.

b) Pamět věcí. Jde o věci, kterými se lidé obklopují a do nichž ukládají své představy o účelovosti, pohodlnosti a kráse: nádobí, nářadí, šaty, nábytek, domy, dopravní prostředky apod. Tyto věci dávají - podobně jako zrcadlo - člověku obraz sebe sama. Assmann říká, že svět věcí obsahuje časový index, který poukazuje na různé vrstvy minulosti.

c) Komunikativní pamět. Je předávána prostřednictvím řeči v mezilidské komunikaci.

d) Kulturní pamět'. Souvisí s tím, že komunikační systém si vytváří vnější oblasti (jakési externí zásobníky), v nichž jsou uloženy informace a sdělení v zakódované podobě. Existence kulturní paměti je podmíněna existencí určitých institucionálních rámců a vyžaduje specialisty, kteří provádějí záznamy v přijatém kódu. Kulturní pamět představuje oblast, do níž předchozí tři typy paměti pronikají a přecházejí. Dochází k tomu např. tehdy, když mimetická rutina přijme status rituálu. Rituál již patří, podle Assmanna, do oblasti kulturní paměti, nebot představuje přenos a zpř́itomňující formu kulturního smyslu. To samé platí i pro věci, pakliže jako např. památný kámen nebo idol - poukazují nejen k určitému účelu (Zweck), ale též smyslu (Sinn) /Assmann 1992: 20-21/.

S problémem vztahu mezi komunikativní a kulturní pamětí souvisí jev, na nějž v šedesátých letech upozornil etnolog Jan Vansina a který označil výrazem the floating gap - „plynoucí mezera“. Vansina se s ním setkal při studiu ústně tradované historie. 
Zjistil, že celkový korpus takto tradovaných obsahů se skládá ze tř́ částí. Pro nejmladší minulost existují bohaté informace. Poté následuje etapa, $\mathrm{z}$ níž se toho v paměti uchovalo velice málo; je tu tedy jakási mezera. A nakonec následují informace o nejstarší době, které jsou opět obsáhlejší a bohatší. U společností, v nichž je historické vědomí tradováno ústně, tedy nacházíme dvě časové úrovně: nejstarší a nejmladší historii. Oblast, která se mezi nimi rozestupuje, se spolu s generacemi pohybuje směrem dopředu; jde tedy o „plynoucí mezeru“.

Komunikativní pamět zahrnuje vzpomínky na čerstvou minulost, o něž se člověk dělí se současníky. Jsou umístěny v horizontu bezprostřední zkušenosti tří až čtyř po sobě jdoucích generací. Vznikají a zanikají se svými nositeli a jsou dnes předmětem oral history, odvětví historického výzkumu, které se nezakládá na písemném svědectví historických pramenů, nýbrž na prrímých vzpomínkách vyprávěných bezprostředními účástníky. Obraz, který se takto vytváríí, představuje „dějiny viděné zespoda“, „dějiny každodennosti“. Výzkumy oral history potvrzují, že i v literárních společnostech nesahají živé vzpomínky za hranici osmdesáti let. Za ní následuje floating gap, který je odděluje od dat školních učebnic, mýtů, oficiálních historických tradic a monumentů.

V kulturní paměti je minulost přetvořena do symbolických figur a je zpř́tomňována v obřadech, které mají sváteční ráz. Figury vzpomínek zakládají skupinovou identitu. Pro kulturní pamět jsou významné nikoliv faktické, nýbrž vzpomínané dějiny. V tomto smyslu je i mýtus skutečný $\mathrm{v}$ té mîre, v které je připomínán a oslavován. Důležitá je jeho normativní a formativní síla. Assmann věnuje pozornost zejména rituálům a slavnostem (primárním organizačním formám kulturní paměti), otázce zprostorovění paměti (které představuje původní médium každé mnemotechniky), památníkům a tradicím.

Mezi komunikativní a kulturní pamětí existuje podle Assmanna polarita, která má radu aspektů. Jedním $\mathrm{z}$ nich je polarita každodennosti a svátku. Rozdíl je i ve struktuře participace a v časové dimenzi. Zatímco účast skupiny na komunikativní paměti je difúzní, kulturní pamět má specializované nositele (šamany, bardy, kněze, učence, umělce). Jestliže je komunikativní pamět ohraničena osmdesáti až sto lety, kulturní pamět sahá až k mytickým počátkům. Komunikativní pamět obsahuje nezformalizované, živé vzpomínky dobových svědků, kulturní pamět je naproti tomu vysoce zformalizovaná a symbolický kódovaná, po př́ípadě inscenovaná literárně, obrazově, dramaticky apod.

$\mathrm{Na}$ otázku, jak si polaritu mezi komunikativní a kulturní pamětí představit, nelze dát podle Assmanna jednoznačnou odpověd'. Mohou to být dva vedle sebe existující samostatné systémy a mohou to být dva extrémní póly jedné škály s plynulým přechodem. Charakter tohoto vztahu je možné posuzovat nikoliv univerzálně, nýbrž pouze konkrétně, prípad od př́padu /op. cit.: $55 \%$. 
Jak již bylo konstatováno, projevuje historie ve srovnání se sociologií o otázku paměti podstatně větší zájem. Už ve dvacátých letech tohoto století zaměřil pozornost na problém sociální paměti a její role v kultuře historik umění Aby Warburg. $\left.{ }^{8}\right) \mathrm{V}$ rámci výzkumného projektu nazvaného Mnemosyne Warburg zpracoval rozsáhlý obrazový atlas, jehož cílem bylo dokumentovat faktory určující vývoj západního myšlení v historickém vývoji od antiky po současnost.

Zvláště živá je v posledních letech otázka paměti mezi francouzskými historiky. Je možné zmínit se např. o Jacquesovi Le Goffovi, který se v knize Dějiny a pamět (vyšla poprvé italsky v r. 1977 pod názvem Storia e memoria) zabývá proměnami lidských představ o čase (minulosti, př́tomnosti, budoucnosti), kolektivními představami a pamětí, vývojem historického vědomí a dějepisectví. Mona Ozouf je historikem, který věnuje pozornost problematice připomínání francouzské revoluce. Ze sociologického hlediska je zajímavé dílo Philippa Arièse, $\mathrm{z}$ něhož můžeme připomenout práci L'homme devant la mort (1977, v německém překladu vyšlo v r. 1980 jako Geschichte des Todes), která je věnována vývoji postojů k smrti v rámci západní civilizace. Tato obsáhlá, mnohasetstránková studie má samostatný knižní obrazový doplněk (byl vydán pod názvem Images de l'homme devant la mort v roce 1983), který na bohatém fotografickém materiálu dokumentuje mj. i jednu z důležitých ,věcných složek" kulturní paměti: památníky, hřbitovy, relikvie, mumie atd.

Do oblasti sociologického výzkumu přesahují některé výzkumné aktivity, které rozvíjí Pierre Nora. Norův zájem o pamět je inspirován Bergsonem a Halbwachsem, ale také Proustem a Freudem. Nora jako historik je do určité míry ovlivněn směrem, reprezentovaným časopisem Annales. Vůči této škole ovšem pocituje i jistou distanci (nikoliv opozici), z nîž do značné míry pramení jeho specifický přístup, vyjádřený v projektu Les lieux de mémoire. Širší kontext tohoto projektu představuje diskuse o muzealizaci historie a světa a o odtržení společnosti od historických tradic v postmoderní epoše.

Nora se hlásí k Halbwachsově koncepci, chápající kolektivní pamě jako konstrukt sociálních, politických, nacionálních, náboženských atd. skupin, přičemž podstatný pro něj není fakt, že je tato pamět komunikována, nýbrž skutečnost, že se manifestuje $\mathrm{v}$ určitém prostoru - v místech paměti. Primárním předmětem Norova zájmu není oral history, nýbrž studium míst (v topografickém ale i symbolickém smyslu) paměti, v nichž podle jeho slov kolektivní pamět „krystalizuje“. Mohou to být budovy, památníky, hřbitovy, ulice, náměstí, symbolická místa spojená s výročími a slavnostmi. Nora se zabývá především francouzskou národní pamětí a historií republiky, přičemž

$\left.{ }^{8}\right)$ Nelze zamlčet, že Warburgovy úvahy o sociální paměti byly do určité míry inspirovány teorií rasové paměti, která se objevila v 19. století, a také názory fyziologa Ewalda Heringa, jenž dokazoval, že pamět je všeobecnou funkcí organické hmoty (Über das Gedächtnis als eine allgemeine Funktion der organischen Materie, 1870). Warburg ovšem zaujímal k těmto teoriím určitý kritický odstup. $\mathrm{V}$ jeho prístupu nalézáme jistou analogii k teorií archetypů $\mathrm{C}$. G. Junga, př́mý Jungův vlivv ovšem nelze prokázat /Gombrich 1981,324-326/. 
v centru jeho zájmu jsou symbolické významy a jejich dějiny. V 90. letech se Norův výzkumný zájem rozšiřuje i na země střední a východní Evropy s cílem zabývat se symbolickými místy, spojenými s jejich totalitní minulostí.

\section{PAMĚŤ A OSOBNÍ IDENTITA}

Doposud jsme se zabývali pamětí kolektivní či skupinovou, tedy jinak řečeno pamětí sociální. Sociologicky relevantní je ovšem i otázka individuální paměti, což např. ve výzkumné oblasti dokládají biografické př́stupy. Nejen v případě identity sociálních útvarů, ale i v př́ípadě osobní identity představuje pamět nepochybně podstatnou determinantu.

$\mathrm{V}$ teoretické rovině na otázku osobní identity upozornili P. Berger a Th. Luckmann v knize The Social Construction of Reality (1966). Berger s Luckmannem v práci, věnované sociální konstrukci reality, rozpracovávají podněty, které ve fenomenologickém směru sociologického bádání rozvinul (v návaznosti na $\mathrm{H}$. Bergsona, $M$. Webera a $E$. Husserla) Alfred Schütz. I když problém vědění patři v tomto díle ke klíčovým, explicitně se oba autoři $\mathrm{k}$ problematice paměti př́liš často nevyslovují. Nicméně pojmy jako typizace nebo zásoba vědní, které představují úhelné kameny této koncepce, existenci paměti tak či onak předpokládají.

Úvahy o osobní identitě, obsažené v knize z r. 1966, rozpracoval během následujících let Th. Luckmann v řadě studií. V nich chápe osobní identitu jako s tělem spojenou, intersubjektivně konstituovanou a sociálně určenou strukturu, která je ve své podstatě časová. Tato struktura je dána syntézou: a) vnitřního (s tělem spojeného) času (Bergsonova durée), b) intersubjektivního času (strukturovaného sociálně objektivizovanými kategoriemi, obsaženými ve společenské zásobě věděnî), v jehož rámci se odehrává synchronizace bezprostřední sociální interakce, a c) biografického času, který je spojen s konstrukcí a rekonstrukcí životního běhu /Luckmann 1986: 141/.

Osobní identita je specifickou formou utváření života, v níž individuum vykonává centrální, vědomou a trvalou kontrolu nad svým chováním. V návaznosti na H. Plessnera charakterizuje Luckmann tuto formu excentricitou, tzn. určitou distancí k situaci „Zde a nyní", která umožňuje individuu umístit se v „historickém“ světě.

Zvláštní význam mají časové kategorie, které Luckmann označuje výrazem „,biografická schémata“. Jsou to kategorie, v nichž je život jednotlivce od narození až do smrti vztažen $\mathrm{k}$ něčemu, co tuto individuální existenci přesahuje, transcenduje $\mathrm{k}$ dějinám, $\mathrm{k}$ sociálním celkům jako rodina, národ, vlast apod. Tato schémata (opět jde o elementy společenské zásoby vědění, které jsou zprostředkovány socializací) dodávají modely pro celý život, pro všechny jeho důležité úseky. Ukazují možné cesty ve světě, který je sociálně, a tím i dějinně zformován, nabízejí jak úctyhodné tak i pochybné verze životů i jeho jednotlivých fází včetně ponaučení, jak tyto fáze vzájemně spojit. Lidé jsou zrozeni na určitém místě a v určitém čase, tedy v jistém socio-historickém apriori. Biografická schémata jsou centrálními stavebními kameny 
tohoto apriori, tvarují individuální život ve více či méně závazné formě a staví ho do vztahu $\mathrm{k}$ transcendujícímu dějinnému času.

Zajímavým způsobem, a to už v r. 1963, ukázal na problém paměti také P. Berger v knize Pozvání do sociologie. Berger zde upozorňuje na skutečnost, že ve svých vzpomínkách rekonstruujeme minulost v souladu se svými nynějšími názory, které určují, co z ní je a není důležité, co je třeba vyzvednout a na co (raději) zapomenout. Zdravý rozum nemá pravdu, když si myslí, že minulost je vzhledem k př́ítomnosti pevná, stálá a neměnná. Právě naopak, je tvárná, poddajná a stále se mění v souvislosti s tím, jak ji znovu a znovu interpretujeme a vysvětlujeme.

Berger poukazuje na to, že zvláště v soudobé americké společnosti, s vysokou zeměpisnou a sociální mobilitou je taková reinterpretace vlastní biografie častým a nápadným jevem. $\mathrm{V}$ jejím důsledku se např. velké emocionální boư̌e minulosti stávají lehkým dětinským vzrušením a lidé, kteří se zdáli být důležití, se mění na omezené hlupáky. Události, na něž byl člověk hrdý, jsou náhle jen epizodami, vyvolávajícími rozpaky a mohou být, jsou-li v rozporu s tím, jak chce nyní myslet, dokonce z paměti vytlačeny /Berger 1991: 56/.

\section{PAMĚŤ JAKO PŘEDMĚT SOCIOLOGICKÉHO VÝZKUMU}

Pokud se dnes sociologové zajímají o otázku paměti, nejde jim ani tak jako třeba historikům o obsahovou stránku minulosti, nýbrž o její formativní a strukturotvorný vliv na současnost a budoucnost (podobně jako když etnologové zkoumají vztah mezi mýty a formou reprodukce sociálních vztahů v archaických společnostech). $\mathrm{V}$ tomto smyslu poukazuje na význam dějin a tradice pro př́tomné chování a rozhodování např. Niklas Luhmann. Luhmann je navíc jedním z mála sociologů, kteří teoreticky analyzují horizont minulého času $v$ jeho všeobecném významu pro výstavbu a reprodukci sociálních systémů /Luhmann 1988/.

Z kritického rozboru Halbwachsových idejí vychází kniha Gerarda Namera $M e^{-}$ moire et société (1987), která se opírá i o poznatky empirických výzkumů. Zvláštní pozornost Namer věnuje kulturní paměti, zejména problematice knihoven a muzeí, a také otázkám paměti v oblasti politiky. Raphael Freddy a Geneviève HerberichMarx jsou sociology, kteří ve své práci věnují pozornost falzifikaci historie a sociálním aspektům zapomínání s ohledem na novodobou francouzskou historii.

Sociologicky inspirativní podněty lze, pokud jde o problém paměti, nalézt nejen $v$ historii, ale i v krásné literatuře. Známé je např. literární ztvárnění motivu vymazávání, opravování a falšování minulosti z Orwellova románu 1984. Na vztah totalitní moci k času, dějinám a paměti poukázala řada autorů esejistickou formou (V. Havel, M. Šimečka a další). Sociologická reflexe těchto jevů prozatím chybí. Naše národní pamět a kolektivní vzpomínky na uplynulá desetiletí jsou látkou, která čeká na své zpracování. Zajímavý výzkumný materiál mohou v tomto směru poskytnou např. i standardní učebnice dějepisu. 
Ostatně i dnes je možné v sociální paměti zaznamenat jistou selektivitu, vytěsňování nepř́íjemných zkušeností a zážitků, exteritorializaci určitých témat (v této souvislosti se někdy hovoří o strukturální amnézii), přepisování individuálních biografií, vytváření nových mýtů, oživování starých ran a resentimentů. Je tu také (a nejenom u nás) znovu otevřený problém identity státní a národní, hovoří se dokonce o její krizi. Slovo identita se stává módním, a to vše opět poukazuje k relevanci námi sledovaného problému.

Empirický sociologický výzkum sociální paměti je zatím spîse okrajovou záležitostí. Určité projekty již ale realizovány byly. Zájem o toto téma je např. u našich rakouských sousedů. Pracovníci Institutu sociologie na fakultě sociálních a hospodárských věd vídeňské univerzity pod vedením prof. Leopolda Rosenmayra se jím zabývají již několik let, přičemž jejich zájem (podobně jako u P. Nory) je dnes orientován na středo a východoevropské postkomunistické země. ${ }^{9}$ )

Rovněž na katedře sociologie FF UK vznikl před časem podobný projekt, pro jehož uskutečnění se ale zatím, vzhledem $\mathrm{k}$ jeho náročnosti, nepodařilo nalézt potřebné finanční krytí. I přes tento prozatímní neúspěch však lze podle mého názoru očekávat, že se téma sociální paměti zanedlouho prosadí i vedle zavedených a tradičních výzkumných problémů, jaké představuje např. zkoumání hodnot, politických postojů nebo sociální stratifikace.

\section{Literatura}

Assmann, J.: Das kulturelle Gedächtnis: Schrift, Erinnerung und politische Identität in frühen Hochkulturen. München, Beck 1992

Ariès, P.: Geschichte des Todes. München, Wien, Carl Hanser Verlag 1980

Ariès, P.: Bilder zur Geschichte des Todes. München, Wien, Carl Hauser Verlag 1984

Berger, P. L.: Pozvání do sociologie, Praha, FMO 1991

Bergson, H.: Vývoj tvořivý. Praha, J. Laichter 1919

Durkheim, E.:Die elementaren Formen des des religiösen Lebens. Frankfurt am Main, Suhrkamp 1981

Durkheim, E.: Pravidla sociologické methody. Praha, Orbis 1926

Freddy, R. - Herberich-Marx, G.: La construction de l'oubli dans la France contemporaine. In: Revue des Sciences Sociales de la France de l'Est. No 17/1989-90

Gombrich, E.H.: Aby Warburg: Eine intellektuelle Biographie. Frankfurt am Main, Europäische Verlagsanstalt 1981

Halbwachs, M.: Das kollektive Gedächtnis. Stuttgart, Ferdinand Enke Verlag 1967

Halbwachs, M.: Spoleczne ramy pamieci. Warszawa, Panstwowe wydawnictwo naukowe 1969

Le Goff, J.: Geschichte und Gedächtnis, Frankfurt am Main, Campus Verlag 1992

Luckmann, T.: Zeit und Identität: Innere, soziale und historische Zeit. In.: Zeit als Strukturelement von Lebenswelt und Gesellschaft. Hrsg. von Fürstenberg, F. und Mörth, I. Linz, R. Trauner Verlag 1986 Luhmann, N.: Soziologische Aufklärung, Bd.2, Opladen, Westdeutscher Verlag 1988

$\left.{ }^{9}\right)$ Jedná se o projekty: Möglichkeiten und Barrieren kulturellen Transfer zwischen den Generationen im posttotalitären Europa der Gegenwart (1992-1993), Die Rolle des Erinnerns bei der gesellschaftlichen Transformation in Ost-Mitteleuropa. Eine empirische Studie zur Gedächtnissoziologie (1992-1993), Nationale Identität in östlichen Nachbarländern (1994-1996). 
Namer, G.: Mémoire et Société. Paris, Méridiens Klincksieck 1987

Nora, P.: Zwischen Geschichte und Gedächtnis. Berlin, Verlag Klaus Wagenbach 1990

Ozouf, M.: Peut-on commémorer la Révolution Francaise. In: Le Débat. No 26, Paris, septembre 1983

Šubrt, J.: K vývoji názorů na problém času v sociologii. In: Sociologický časopis 4/1993

Unfried, B.: Gedächtnis und Geschichte: Pierre Nora und die lieux de mémoire. In: Österreichische Zeitschrift für Geschichtswissenschaften 4/1991

\section{Memory as a Sociological Phenomenon}

\section{Summary}

The first sociologist to deal with memory in any significant ly way the French sociologist, M. Halbwachs, who was most influen ced by his teachers H.Bergson and E. Durkheim. Halbwachs talks about the social contingency of memory. In his view, memory is constituted, functions and is reproduced in certain social frames. Halbwachs deals with the collective memory of a family, religious societies, social classes and nations. Interest in Halbwachs' work was renewed in the 1980's, and today his ideas especially interest historians.

Another sociologist of memory Jan Assmann distinguishes 4 spheres of memory: a) mimetic memory, b) memory of things, c) communicative memory, d) cultural memory. Communicative memory contains recall of the recent past which is located within the ex perience of the last $3-4$ generations, and which is the subject of historical research referred to as oral history. In cultural memo ry, the past is changed into symbolic figures and is presented in rituals of a festive character. Cultural memory reaches the mythi cal beginnings. While the presence of a group in the communicative memory is diffuse, cultural memory has specific bearers, and is highly formalised and symbolicly coded, perhaps articulated or ex pressed literary or throughout dramatic forms.

Halbwachs conception of collective memory is supported also by Pierre Nora for whom the significant fact is not its being communicated but that it is manifested in a certain space - that of memory. The primary subject of Nora's interest is the study of memory space (in a topographic and symbolic sense), where collec tive memory is "crystalized".

The issue of individual memory is sociologically significant, as evidenced by biographic approaches to history, social issues. Theoretically significant is the issue of personal identity, with which P.Berger and Th.Luckmann deal. Luckmann considers personal identity as connected to a body and, intersubjectivelly constitu ted. It is a socially determined structure which is essentially based on time. This structure is a synthesis of: a) inner time (connected with the body and analogous to Bergson's duree), b) in tersubjective time (structured by socially objectivized categories contained in social knowledge), in the framework of which synchro nisation of social interaction takes place; and c) biographic ti me, which is connected with the construction and reconstruction of the course of life.

Empirical sociological research of social memory is so far not extensive but certain projects have been completed (e.g. by the Institute of Sociology at the University of Vienna). 